Nevada

Environmental

Restoration

Project

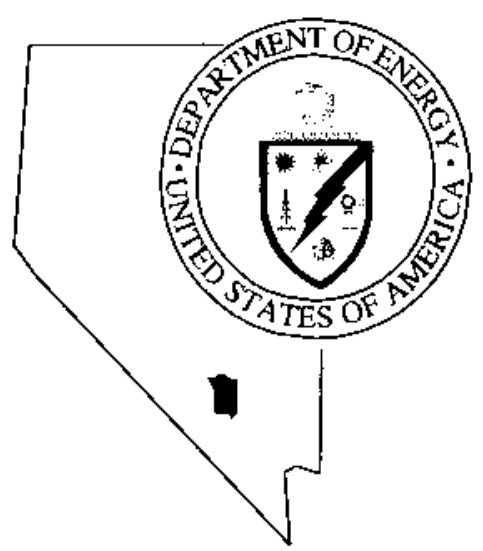

Addendum to the

Corrective Action Investigation Plan for Corrective Action Unit 447:

Project Shoal Area, Nevada

Subsurface Site

Controlled Copy No.:

Revision No.: 1

April 1999

Approved for public release; further dissemination unlimited.

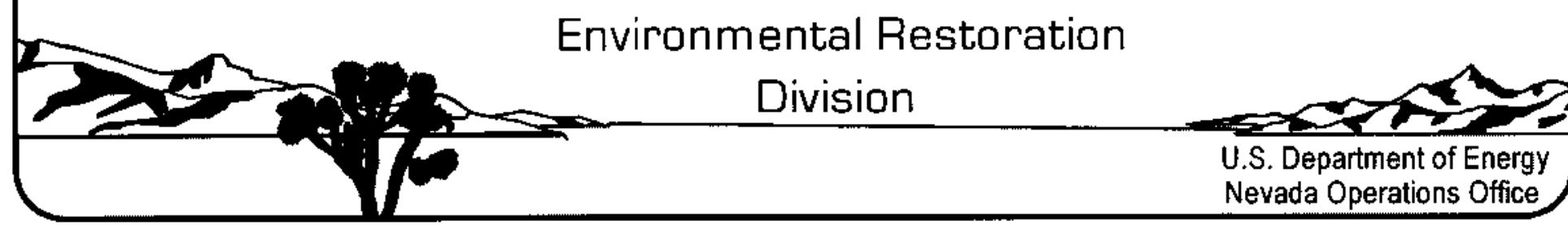




\title{
ADDENDUM TO THE CORRECTIVE ACTION INVESTIGATION PLAN FOR CORRECTIVE ACTION UNIT 447: PROJECT SHOAL AREA, NEVADA SUBSURFACE SITE
}

\author{
DOE Nevada Operations Office
}

Las Vegas, Nevada

Controlled Copy No.:

Revision No.: 1

April 1999

Approved for public release; further dissemination unlimited. 
Available to the public from -

U.S. Department of Commerce

National Technical Information Service

5285 Port Royal Road

Springfield, VA 22161

(703) 487-4650

Available electronically at http://www.doe.gov/bridge. Available to U.S. Department of Energy and its contractors in paper from -

U.S. Department of Energy

Office of Scientific and Technical Information

P.O. Box 62

Oak Ridge, TN 37831-0062

(423) 576-8401 


\title{
ADDENDUM TO THE CORRECTIVE ACTION INVESTIGATION PLAN \\ FOR CORRECTIVE ACTION UNIT 447: \\ PROJECT SHOAL AREA, NEVADA SUBSURFACE SITE
}

\begin{abstract}
Signature Approved
Approved by:

Monica L. Sanchez, Project Manager

Offsites Subproject
\end{abstract}

Date:

$4 / 13 / 99$

Signature Approved

4/13/99

Approved by:

Runore C. Wycoff, Division Director

Environmental Restoration Division

Date: 


\section{Preface}

The following represents an addendum to Chapter 6.0, "Field Investigation," of the Corrective Action Investigation Plan for Corrective Action Unit 447: Project Shoal Area, Nevada Subsurface Site, DOE/NV--513. Sections 6.0 and 6.1 in DOE/NV--513 continue to stand, with the sections below following after them. These new sections represent information that was not available at the time DOE/NV--513 was issued. 


\section{Table of Contents}

Preface $\ldots \ldots \ldots \ldots \ldots \ldots \ldots \ldots \ldots \ldots \ldots \ldots \ldots \ldots \ldots \ldots \ldots \ldots \ldots$

List of Figures $\ldots \ldots \ldots \ldots \ldots \ldots \ldots \ldots \ldots \ldots \ldots \ldots \ldots \ldots \ldots \ldots \ldots \ldots$

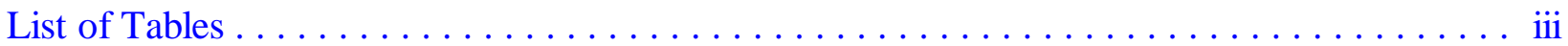

List of Acronyms and Abbreviations $\ldots \ldots \ldots \ldots \ldots \ldots \ldots \ldots \ldots \ldots \ldots \ldots \ldots \ldots$

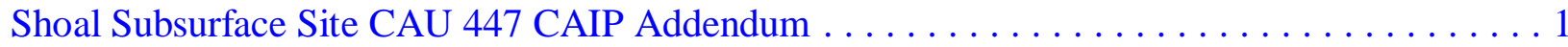

6.2 Data Decision Analysis Results and Data Collection Recommendations . . . . . . . . 1

6.2.1 Rationale for Proposed Activities: Results of the Data Decision Analysis . . . . 1

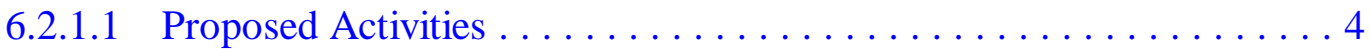

6.2.2 Description of Proposed Field Activities $\ldots \ldots \ldots \ldots \ldots \ldots \ldots \ldots$

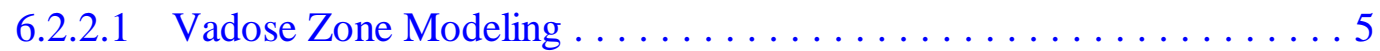

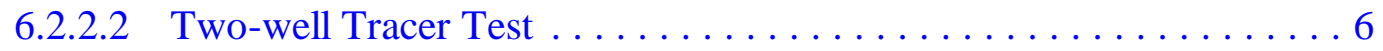

6.2.2.3 Environmental Tracer/Deep-Well Hydraulic Characterization . . . . . . 8

Addendum to 9.0 References of the CAIP . . . . . . . . . . . . . . . . . . . . 10 


\section{List of Figures}

Number

Title

Page

6.2-1 Expected Model Uncertainty Reduction from the Field Activities

Versus Estimated Costs for the Mean Breakthrough Time Metric . . . . . . . . . . . 4

6.2-2 Approximate locations and target depths for proposed new wells at the Shoal site, relative to existing wells and Ground Zone . . . . . . . . . . 7

\section{List of Tables}

Number

Title

Page

6.2-1 Prior Distributions for the Input Parameters $\ldots \ldots \ldots \ldots \ldots \ldots \ldots \ldots \ldots$

6.2-2 Reduction in Model Uncertainty of Mean Breakthrough Time for the Nine Input Parameters Assuming Each Parameter is Known with

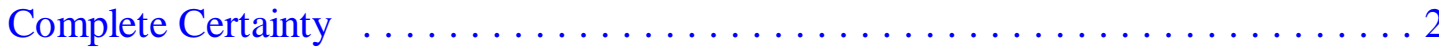

6.2-3 The Ranked Uncertainty Reduction of Mean Breakthrough Time

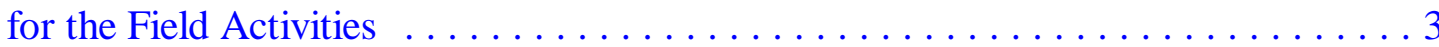


Page iv of iv

\section{List of Acronyms and Abbreviations}

CAIP Corrective Action Investigation Plan

DDA Data decision analysis 


\section{Shoal Subsurface Site CAU 447 CAIP Addendum}

\subsection{Data Decision Analysis Results and Data Collection Recommendations}

Chapter 6.0 in the Shoal Subsurface Corrective Action Investigation Plan (CAIP) provided a framework for a data decision analysis (DDA) that would be used to determine investigation methods and data collection methods to minimize uncertainty in groundwater flow and transport predictions. Uncertain parameters were identified and possible field activities that could provide information on those uncertain parameters were briefly described. The DDA has now been completed (Pohll and Forsgren, 1999) and prompts this addendum to describe the outcome of the DDA, how it was used to determine the next phase of data collection for the Shoal Subsurface activities, and to provide details of the planned investigations sufficient to allow understanding of the scope and completion of the tasks involved.

\subsubsection{Rationale for Proposed Activities: Results of the Data Decision Analysis} The methodology followed in the DDA is presented in both Section 6.0 of the CAIP and in Pohll and Forsgren (1999). The numerical flow and transport model previously developed for the Shoal site (Pohll et al., 1998) was used to identify the nine uncertain parameters considered in the analysis. These parameters were presented in the CAIP and are as follows: effective porosity, hydraulic head at the downgradient boundary, recharge, hydraulic conductivity, fracture connectivities, fracture orientations, fracture dip, glass dissolution rate, and retardation.

Prior distributions of these parameters (mean, minimum, and maximum values) were assigned using site-specific data or literature values (Table 6.2-1). In most cases, the distribution was assumed to be uniform, but for effective porosity and glass dissolution rate, a uniform distribution in $\log _{10}$ space was used given the very wide range in possible values. These prior distributions, reflecting the current knowledge of input uncertainty, were used to calculate the full uncertainty in the flow and transport model. The reduction in uncertainty, if a single parameter was perfectly known, was then calculated for each uncertain value. Two metrics of uncertainty reduction were evaluated: mean breakthrough time and peak concentration, and provided similar results. These uncertainty reductions (Table 6.2-2) reflect the relative contribution of each parameter to model uncertainty; the calculated reductions would never actually be achieved, because no parameter can be perfectly known. 
Table 6.2-1

Prior Distributions for the Input Parameters

\begin{tabular}{lcccccc}
\hline \hline \multicolumn{1}{c}{ Parameter } & Minimum & Mean & Maximum & Variance & Distribution & Source \\
\hline Porosity & -3.3 & -2.65 & -2 & 0.14 & Uniform of Log \\
Hydraulic Head & 1,150 & 1,185 & 1,220 & 408 & Uniform & PSA Data \\
Recharge & 0.2 & 1.1 & 2 & 0.27 & Uniform & PSA Data \\
Variance K & 0 & 1 & 2 & 0.33 & Uniform & Literature \\
Fracture & 50 & 375 & 700 & 35,000 & Uniform & PSA Data \\
$\quad$ Correlation Scale & & & & & & \\
$\quad$ Fracture Orientation & 8 & 29 & 50 & 147 & Uniform & PSA Data \\
Dip Angle & 30 & 60 & 90 & 300 & Uniform & PSA Data \\
Glass Dissolution & -8.39 & -6.69 & -4.69 & 1.33 & Uniform of Log L $_{10}$ & Literature \\
Retardation & 1.57 & 1.73 & 1.88 & 0.01 & Uniform & PSA Data \\
\hline \hline
\end{tabular}

Table 6.2-2

Reduction in Model Uncertainty of Mean Breakthrough Time for the Nine Input Parameters Assuming Each Parameter is Known with Complete Certainty

\begin{tabular}{lcccc}
\hline \hline \multicolumn{1}{c}{$\begin{array}{c}\text { Ranked Parameters by } \\
\text { Variance Reduction } \\
\text { Metric: Mean Breakthrough Time }\end{array}$} & $\begin{array}{c}\text { Log }_{10} \\
\text { Standard } \\
\text { Deviation }\end{array}$ & $\begin{array}{c}\text { Percent } \\
\text { Reduction }\end{array}$ & $\begin{array}{c}\text { 95 Percent Confidence Interval } \\
\text { Low (years) High (years) }\end{array}$ \\
\hline Porosity & 0.241 & 38.0 & 82 & 726 \\
Recharge & 0.294 & 24.6 & 65 & 918 \\
Correlation Scale & 0.373 & 4.1 & 45 & 1,315 \\
Dip & 0.380 & 2.3 & 44 & 1,358 \\
Head & 0.381 & 2.0 & 44 & 1,364 \\
Dissolution Rate & 0.385 & 1.1 & 43 & 1,387 \\
Variance Conductivity & 0.386 & 0.9 & 43 & 1,392 \\
Retardation & 0.387 & 0.7 & 43 & 1,397 \\
Strike & 0.399 & 0.7 & 42 & 1,412 \\
\hline \hline
\end{tabular}

The result of the single parameter uncertainty analysis was identification of effective porosity and recharge as the parameters contributing the largest amount of uncertainty to the model. Therefore, reduction of uncertainty in the possible range in those parameter values will provide the largest reduction in overall model uncertainty.

Posterior distributions for each parameter were also estimated, based on an evaluation of the reliability for a wide range of possible field activities to provide data on the parameter. These posterior distributions were then used in Monte Carlo simulations with the flow and transport model to calculate the reduction in model uncertainty that would be gained by performing each field activity. This calculation allowed ranking of the potential activities in terms of uncertainty reduction (Table 6.2-3). 
Table 6.2-3

The Ranked Uncertainty Reduction of Mean Breakthrough Time for the Field Activities

\begin{tabular}{lcccc}
\hline \hline \multicolumn{1}{c}{$\begin{array}{c}\text { Ranked Parameters by } \\
\text { Variance Reduction }\end{array}$} & $\begin{array}{c}\text { Log }_{10} \\
\text { Metric: Mean Breakthrough Time }\end{array}$ & $\begin{array}{c}\text { Percent } \\
\text { Deviation }\end{array}$ & Reduction & 95 Percent Confidence Interval \\
\cline { 5 - 6 } Natural-gradient Test & 0.215 & 44.8 & 93 & Low (years) \\
Nigh (years) \\
Two-well Tracer Test & 0.237 & 39.2 & 84 & 643 \\
Tracer Techniques & 0.250 & 35.7 & 79 & 755 \\
Single-well Tracer Test & 0.274 & 29.5 & 71 & 842 \\
Barometric Test & 0.305 & 21.6 & 62 & 966 \\
Cross-hole Packer Test & 0.323 & 17.1 & 57 & 1,048 \\
Single-hole Packer Test & 0.327 & 15.9 & 56 & 1,069 \\
Hydraulic Head Measurement & 0.331 & 15.0 & 55 & 1,087 \\
Energy Budget & 0.333 & 14.6 & 54 & 1,094 \\
Vadose Zone Model & 0.333 & 14.6 & 54 & 1,094 \\
Borehole Scanner & 0.344 & 11.7 & 52 & 1,152 \\
Cavity Drillback & 0.351 & 9.8 & 50 & 1,189 \\
Acoustic Televiewer & 0.357 & 8.3 & 59 & 1,221 \\
Oriented Video & 0.357 & 8.3 & 59 & 1,221 \\
Temperature Profiles & 0.358 & 8.0 & 49 & 1,227 \\
Neutron Logs & 0.364 & 6.4 & 47 & 1,263 \\
Gamma-gamma Log & 0.364 & 6.4 & 47 & 1,263 \\
Flowmeter Testing & 0.366 & 5.9 & 47 & 1,275 \\
Mining Drift Data & 0.380 & 2.4 & 44 & 1,356 \\
Analogues & 0.380 & 2.3 & 44 & 1,359 \\
Retardation Experiment & 0.389 & 0.0 & 42 & 1,415 \\
\hline \hline
\end{tabular}

By combining the uncertainty reduction estimates for the field activities with preliminary cost estimates, a cost-benefit analysis was performed. Presented graphically (Figure 6.2-1), activities that plot in the area of lower cost and higher uncertainty reduction are optimal. The analysis for Shoal identified five optimal field activities: vadose zone modeling, energy budget techniques, single-well tracer test, two-well tracer test, and natural gradient tracer test. Both the vadose modeling and energy budget techniques provide information regarding recharge rates, while the tracer tests provide information on effective porosity. The relationship between these optimal activities and the parameter uncertainty analysis is clear: the large uncertainty presented by effective porosity and recharge lead to the greatest gains in uncertainty reduction for field activities that reduce uncertainty in those parameters. 
Fiold Achrity Numbors

\begin{tabular}{|c|c|c|}
\hline $\begin{array}{l}\text { Two-well Tracar } \\
\text { Baromedzicivapar Ext. } \\
\text { Cross-hole Pactker } \\
\text { Hydraulic Head } \\
\text { Nalural Gradienl }\end{array}$ & $\begin{array}{l}8 \\
7 \\
8 \\
0 \\
10\end{array}$ & $\begin{array}{l}\text { Single-well Packer } \\
\text { Emvrdsmenlal Traced } \\
\text { Single-well Tracer } \\
\text { Energyt Budget } \\
\text { Wadosc Lono Modeling }\end{array}$ \\
\hline
\end{tabular}

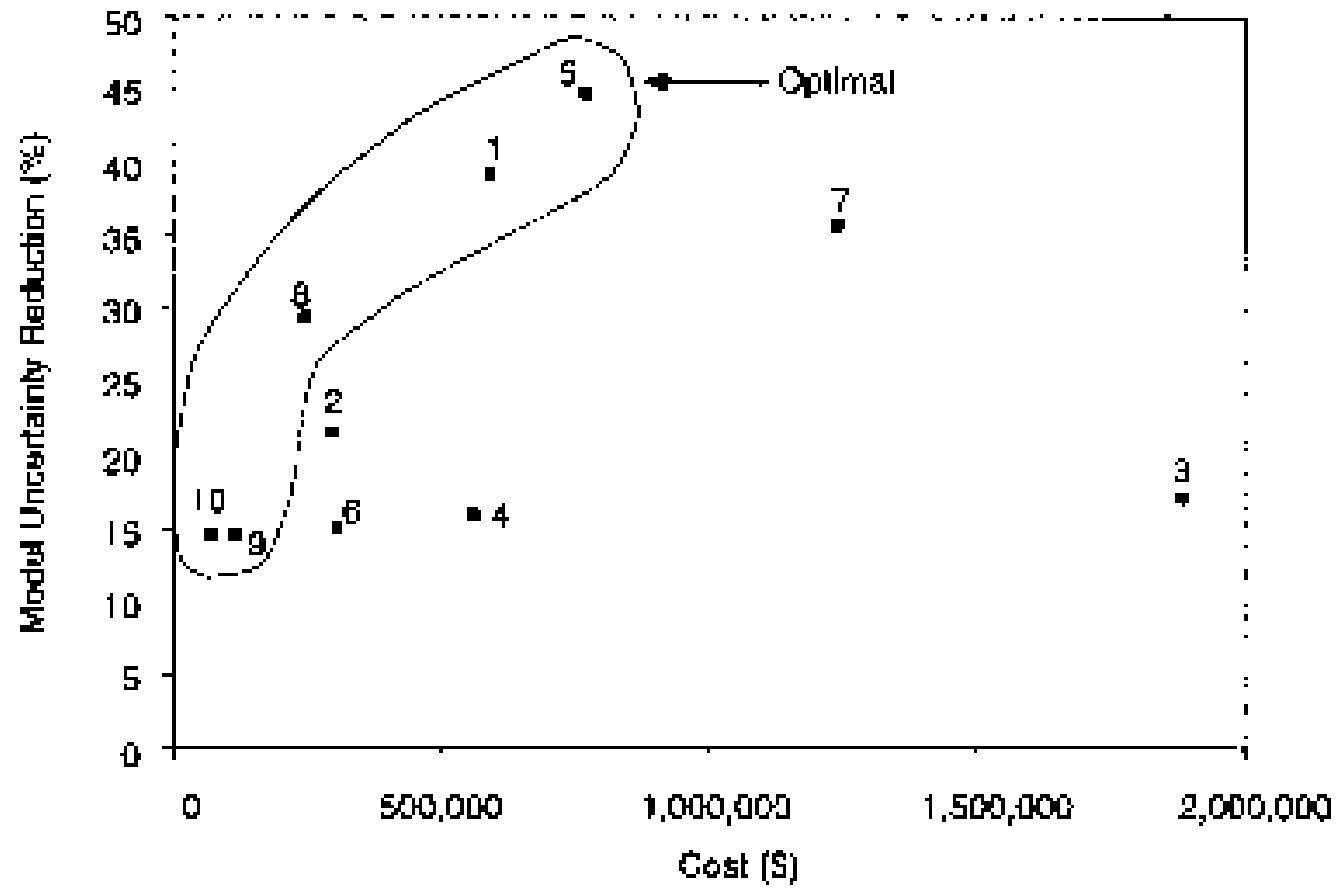

Figure 6.2-1

Expected Model Uncertainty Reduction from the Field Activities Versus Estimated Costs for the Mean Breakthrough Time Metric

\subsubsection{Proposed Activities}

Three activities are proposed as a result of the DDA: vadose zone modeling, a two-well tracer test, and an environmental tracer/deep-well hydraulic characterization test. Although the results of the DDA analysis suggest that five of the ten activities are optimal, budget and scheduling constraints limit the number of activities that can be implemented. Therefore, field activities were chosen such that the work could be completed in a reasonable amount of time and within budget constraints. The selection was also guided by the fact that the optimal field activities reflect some duplication; the five activities fall into two base groups. Three of the five optimal activities are tracer tests, while the other two address reducing uncertainty in recharge. Each of the tracer tests rank high, because they each provide information on effective porosity, but 
performing all of them would not provide significantly more information. The two-well tracer test (\#1) was chosen as the preferred tracer test, because it is less expensive and requires much less time to implement ( 4 mo vs. >1 yr) than the natural gradient test (\#5), yet provides more uncertainty reduction than the single-well tracer test (\#8). Likewise, the vadose zone modeling activity (\#10) was selected over the energy budget (\#9) for the recharge activity, because it required less time to implement, and has a lower cost. The two-well tracer test (\#1) and the vadose zone modeling (\#10) would provide information on the two most critical parameters: effective porosity and recharge, yet these activities do not characterize the deeper part of the groundwater flow system. A third activity, the environmental tracer/deep well characterization (\#7) was selected to provide characterization information at depths not previously investigated. This activity did not rank as optimum because of its relatively high cost. Nevertheless, activity \#7 is proposed because it will provide valuable information on the fracture hydraulics from depths not previously investigated and may prove invaluable in supporting the conceptual model for flow at the Shoal site.

\subsubsection{Description of Proposed Field Activities}

The following sections describe the proposed field activities.

\subsubsection{Vadose Zone Modeling}

After effective porosity, uncertainty in recharge dominated the DDA. Two possible tasks were identified that addressed the recharge component: vadose zone modeling and energy budget measurements. Both of these activities ranked essentially equivalent in the cost-benefit analysis. Vadose zone modeling was selected because the energy budget measurements would require at least 12 months of field data collection and even then be subject to uncertainties regarding precipitation at the site. The energy budget essentially measures bare soil evaporation and evapotranspiration which, when combined with precipitation data, can be used to estimate net surface recharge. However, precipitation in semi-arid regions such as Shoal has marked variability from season-to-season and year-to-year, requiring long periods of record to obtain meaningful average values. For these reasons, the vadose zone modeling was selected as the activity to address uncertainty in recharge.

For the vadose zone modeling task, available meteorological data from the region will be used in conjunction with available hydraulic data from the Shoal subsurface. State of the art vadose zone models will be used for hypothesis testing of various recharge and hydraulic conductivity relationships. The goal of the modeling is to identify ranges of possible recharge rates that 
provide the system response (e.g., water levels) found at the Shoal site. Comparison of the modeling results of various combinations of recharge and hydraulic conductivity with known system characteristics will allow elimination of some combinations and reduction in uncertainty about the true values.

\subsubsection{Two-well Tracer Test}

The DDA determined that reducing uncertainty in the effective porosity provided the largest reduction in model uncertainty, as measured by both the mean breakthrough time and peak concentration metrics. Field activities that provide information on effective porosity thus also provide the most significant uncertainty education. Of these field activities (natural-gradient tracer test, two-well tracer test, tracer techniques, single-well tracer test, and barometric tests), the two-well tracer test was selected for providing data on effective porosity. Upon evaluation of the potential tracer tests, the two-well tracer test was determined to be best-suited for the Shoal site because it provides direct information regarding effective porosity, in a timely manner. Single-well tests require many assumptions that could limit the reliability of the interpretations. Natural gradient tests provide high-quality information, but tracer breakthrough can take many years.

The purpose of the two-well forced-gradient tracer test will be to determine subsurface hydraulic parameters, including effective porosity. A tracer will be injected into the fractured granite aquifer at one well while monitoring and pumping a second, downgradient well. Since the exact test protocol is currently being developed, the preliminary design presented below may be altered as planning proceeds or in response to conditions encountered in the field.

The test will be conducted in two shallow wells (HC-6 and HC-8), approximately 30 meters apart, installed in the upper portion of the aquifer. The first choice for this will be at the well-nest location (Figure 6.2-2) for the environmental tracer/deep-well hydraulic characterization work, as this is proposed in the general downgradient direction from the Shoal cavity. In addition to geographic location, the test must be located in a well that can sustain a pumping rate of up to 5 gallons per minute without incurring large drawdowns. This latter requirement is known to be met at existing well HC-4. If after drilling and testing the new well nest, hydraulic conductivity at the shallow well is not sufficient, the tracer test may be moved to the HC-4 location, and the tracer well will be drilled adjacent to HC-4. The other existing Shoal wells are less desirable for the test location (HC-1 is very deviated from vertical, $\mathrm{HC}-2$ has low hydraulic conductivity, and HC-3 does not have adequate downhole access). 


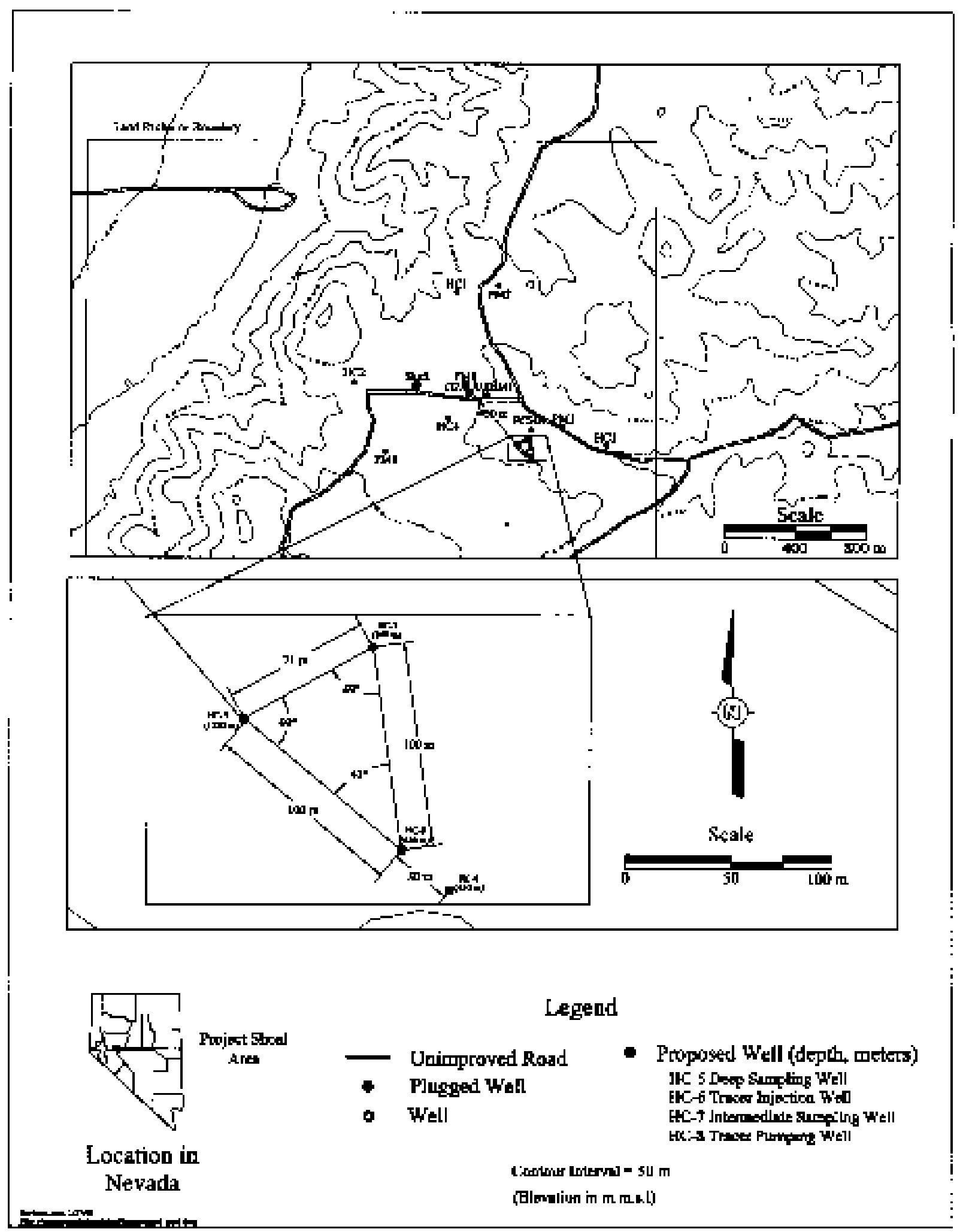

Figure 6.2-2

Approximate locations and target depths for proposed new wells at the Shoal site, relative to existing wells and Ground Zone. If the hydraulic conductivity of HC-6 is not high enough for a successful tracer test, $\mathrm{HC}-8$ will be drilled $\mathbf{3 0}$ meters from $\mathrm{HC}-4$, and HC-4 and HC-8 will be used for the tracer experiment. 
Geophysical logging and well development will precede the tracer test. The downgradient well (HC-8) will be pumped into a nearby sump (the fluids will not be recirculated). After water levels equilibrate, multiple tracers will be introduced at low injection rates in the up-gradient well (HC6). Multiple tracers will be used to investigate both physical and chemical properties of the aquifer. Tracers under consideration are fluorinated benzoic acids (a heavy molecule to determine the influence of matrix diffusion), chloride (a halide anion to serve as a conservative tracer), and magnesium (a reactive cation). The test is expected to require four months of pumping to obtain sufficient breakthrough for interpretation.

\subsubsection{Environmental Tracer/Deep-Well Hydraulic Characterization}

As suggested by the name, the environmental tracer/deep-well hydraulic characterization activity has multiple objectives. These objectives are: (1) provide samples from several depths in the groundwater flow system for groundwater velocity determination using environmental tracers; (2) measure hydraulic head variation with depth; (3) specifically, determine head in the first zone of saturation to address uncertainties raised by the water level history of HC-3; (4) document fracture frequency with depth and other characteristics (strike, dip, aperture) if possible; (5) determine fracture continuity between the boreholes of the nest; and (6) measure hydraulic conductivity as a function of depth.

The environmental tracer aspect was the objective evaluated in the DDA. Using a radioactive tracer in conjunction with flow-path information from the numerical flow model, an independent measure of groundwater velocity can be derived. Specifically, carbon-14 will be used to estimate the groundwater residence time versus depth. If groundwater ages exceed the range of investigation of carbon-14 (approximately 30,000 years), samples will be analyzed for the longer half-lived chlorine-36. The well depths (at the water table, and at approximately 750 and 1,200 meters below ground surface) were selected to provide sufficient differences in residence time for the analysis, though spatial variability in velocity throughout the flowfield could mask the vertical differences at one location.

In order to meet the objective of obtaining samples from these depths for environmental tracer analysis, a new well was needed that would be much deeper than any upon which the current groundwater characterization is based. This is particularly significant given the projected groundwater flow from the Shoal cavity; the current flow model describes a plume that plunges vertically before moving laterally out toward Fairview Valley. Given this, the hydraulic objectives were added in order to obtain data in this possible zone of radionuclide transport. The 
vertical hydraulic gradient, as derived from head measurements in discrete depth intervals, will be used to confirm and quantify the modeled downward flow at the site and further constrain the recharge process that drives that flow. Though of less significance to the uncertainty reduction in the DDA, the uncertainty in the shallow hydraulic head in the downgradient portion of the model will also be addressed by these measurements. Measurements of fracture characteristics and hydraulic conductivity with depth will identify if fracture frequency and hydraulic conductivity decrease with increasing depth. Tighter formations, particularly in fractured terrain, are intuitively likely with depth, but without supporting data could not be justified in the previous flow model. If decreased fracture frequency and conductivity are found, this may significantly alter the conceptual model of the site.

The plan is to access three different depths (as described above) using a well cluster, or "nest." A single well with multiple completions was considered, but not pursued, because of the much greater complexity and risk associated with multiple completions and the significantly higher testing cost. The well nest provides several distinct advantages. The simpler well design reduces the possibility of contamination of the sample interval by cement, or cross-contamination by water from other horizons. The single completion will assure equilibrated head measurements of discrete zones. The close well spacing provides an opportunity to evaluate the continuity of fractures in three-dimensions, another important feature of the numerical model. The additional fracture characterization and hydraulic testing will also enhance the estimation of spatial variability in fracture classes and hydraulic classes, throughout the site. Though not an explicit objective during the characterization process, the single completions also increase the possibility that the wells could have value as future monitoring wells.

The well nest will be located downgradient of the nuclear test in the current numerical model (Figure 6.2-2). Each well will have a single completion, probably about 30 meters of screen, near its total depth and located based on logging. One well (HC-6) will be completed at the water table, while the deepest well (HC-5) will be approximately 1,200 meters below ground. The final well (HC-7) will be located at an intermediate depth, targeted at 750 meters. The wells will be spaced in a triangle to facilitate the spatial correlation of fractures. Geophysical logging, video logging, and stressed flowmeter testing will precede well construction to allow the maximum information to be gained from the open hole. After the well is installed, well development and an aquifer test will be performed using a submersible pump. Once the drilling fluid has been removed (drilling fluids will be tagged with bromide, which will then be monitored during purging), water samples will be collected for environmental tracer and chemical analysis. 


\section{Addendum to 9.0 References of the CAIP}

Pohll, G., J. Tracy, and F. Forsgren. 1999. Data Decision Analysis: Project Shoal, DOE/NV/11508--42, Water Resources Center Publication 45166, 27 p. Las Vegas, NV: Desert Research Institute.

Pohll, G., J. Chapman, A. Hassan, L. Papelis, R. Andricevic, and C. Shirely. 1998. Evaluation of Groundwater Flow and Transport at the Shoal Underground Nuclear Test, DOE/NV/11508-35, Publication \#45162. Las Vegas, NV: Desert Research Institute, Water Resources Center. 


\section{Distribution List}

\section{$\underline{\text { Controlled Copies }}$}

Paul J. Liebendorfer

Bureau of Federal Facilities

Division of Environmental Protection

333 W. Nye Lane, Room 138

Carson City, NV 89706-0851

Michael D. McKinnon

Bureau of Federal Facilities

Division of Environmental Protection

555 E. Washington, Suite 4300

Las Vegas, NV 89101

Sabrina D. Lawrence

DOE/Nevada Operations Office

Environmental Restoration Division

P.O. Box 98518, M/S 505

Las Vegas, NV 89193-8518

Rosa Silver

IT Corporation

P.O. Box 98521, M/S NTS306

Las Vegas, NV 89493-8521

$\underline{\text { Uncontrolled Copies }}$

Monica L. Sanchez

DOE/Nevada Operations Office

Environmental Restoration Division

P.O. Box 98518, M/S 505

Las Vegas, NV 89193-8518

Peter A. Sanders

DOE/Nevada Operations Office

Environmental Restoration Division

P.O. Box 98518, M/S 505

Las Vegas, NV 89193-8518 


\section{$\underline{\text { Uncontrolled Copies }}$}

Jenny Chapman

Desert Research Institute

P.O. Box 19040, M/S 433

Las Vegas, NV 89132

David D. Madsen

Bechtel Nevada

P.O. Box 98531, M/S NTS306

Las Vegas, NV 89193-8521

U.S. Department of Energy

Nevada Operations Office

Technical Information Resource Center

P.O. Box 98518, M/S-505

Las Vegas, NV 89193-8518

U.S. Department of Energy

Office of Scientific and Technical Information

P.O. Box 62

Oak Ridge, TN 37831-0062

U.S. Department of Energy

Nevada Operations Office

Public Reading Facility

P.O. Box 98521, M/S NLV040

Las Vegas, NV 89193-8521

Paul Gretsky

IT Corporation

P.O. Box 98521, M/S NTS306

Las Vegas, NV 89493-8521

IT Corporation Central Files

IT Corporation

P.O. Box 98521, M/S NTS306

Las Vegas, NV 89493-8521
1 (Electronic)

1

1 (Controlled)
5 